\title{
Determinants of Capital Structure for Malaysian Shariah-Compliant Firms: The Impact of Revised Screening Methodology
}

Norfhadzilahwati Rahim*

Fauzias Mat Nor

Nurainna Ramli

Ainulashikin Marzuki

Faculty of Economics and Muamalat, Universiti Sains Islam Malaysia, Malaysia

*Corresponding author: fhadzilahwati@raudah.usim.edu.my

\section{A R T I C L E I N F O}

Article history:

Received 10 April 2019

Revised 15 August 2019

Accepted 29 August 2019

Published 6 January 2020

Keywords:

Capital Structure, Malaysian public-listed shariah-compliant firms, panel data analysis.

JEL Codes: G32.

\section{A B S T R A C T}

This study investigates two main objectives. Firstly, the determinants of capital structure were examined for each sector among Malaysian Shariah-compliant firms, and whether the inclusion of Islamic debt (leverage 1 and leverage 2) has led to different results due to changes in the screening methodology. Secondly, this paper analyzes the target Capital Structure and Speed of Adjustment for both before and after the Revised Screening Methodology. This study employs panel data analysis by using generalized method of moment (GMM). The sample consists of 192 Shariah-compliant companies in Malaysia during the period of 1999 to 2017 . The results demonstrated that the firm has target capital structure and identified specific determinants that have affected the capital structure of 
Shariah-compliant firms in Malaysia. Moreover, the findings have also revealed certain implications toward large firms. Large firms tend to generate more income and profit, however at the same time, these firms require more debt to support investment activities. Hence, with regards to profitability, this study identified a negative relationship between profitability and leverage for Shariah-compliant firms for all sectors. Shariah-compliant firms with high profitability will use a lower leverage in their financial activities. Thus, the results strongly support the pecking order theory. Other than that, this study found that the lagged dependent variable (lagged leverage 1 and leverage 2 ) presented a positive significance, and concluded that the speed of adjustment takes approximately 2 years. This suggests that the Shariah-compliant firms close approximately by $30 \%$ to $70 \%$ of the gap between current and target capital structure within one and two years. Furthermore, the findings on the target leverage level imply that after the revised screening methodology was introduced in November 2013, the speed of adjustment became faster than before the implementation of the new screening methodology. Thus, it is important for management to maintain the target leverage during financial decision making, which in turn strengthens the firm's Shariahcompliant financial stability and sustainability, and continue to remain listed as Shariah-compliant securities. This paper provides an overview of capital structure behaviour in Malaysia. 


\section{Introduction}

In the arena of corporate finance, capital structure is a very important aspect of a company's investment choice as this will affect the company's value and financial risk. This topic is one of the most debated issue in the finance literature. Many researchers have conducted studies on its theories, and obtained empirical evidences on the factors that have influenced the choice of capital structure, optimum capital structure and the influence of capital structure on the value of the firm. Based on the pecking order theory, a company is required to fund the financial asset by retaining earnings at the beginning. However, if the company faces financial problems, it must raise funds on debt, followed by equity. However, the use of debt is limited as companies might face bankruptcy that would affect the long term prosperity of the company, which in turn relates to how managers deal and operate the company's capital structure (Johnson \& Soenen, 2003).

Capital structure decisions are influenced by firm-specific factors (Haron, 2016). The examples for firm-specific factors are profitability, business risk, firm size, liquidity and share price performance. In addition to the capital structure decision, the speed of adjustment occur when firms have either a higher or lower debt, or when the firm face a financial surplus or deficit (Byoun, 2008). Thus, firms will move towards the target capital structure when companies experience a financial deficit or surplus. By identifying the factors that influence capital structure decision, companies would be able to move towards value maximization that would further strengthen the company's financial stability.

In 2013, the Securities Commission Malaysia (SC) revised the screening methodology for the operating, financing and investing criteria of the listed firms. The new criteria added into the Shariah screening methodology is financial ratio benchmarks. It is based on two ratios; cash over total assets and debt over total assets. The limit set for the financial ratio benchmarks is 33 percent, whereby a firm is required to have 33 percent of its holdings of cash or cash equivalents in conventional deposits or accounts, and conventional debts or borrowings for companies listed as Shariah-compliant firms. Due to this revision, the number of listed Shariah-compliant firms were reduced to 653 firms (71.4 percent) out of the total 914 firms from the listed securities on the Bursa Malaysia. The main reason for the reduced listed Shariah-compliant companies is due to the firms having a higher level of conventional debt which exceeded the 33 percent limit that was set by the SC. Therefore, in order to remain listed as a Shariahcompliant company, the alternative option is to take up Islamic debt after hitting the 33 percent limit. In other words, by managing financial leverage, companies can enhance the Shariah-compliant financial stability while remaining listed as Shariah-compliant securities.

Furthermore, the identification of the determinants of capital structure in Malaysian Shariah-compliant firms have continued to spark debates, and is due to the lack of previous empirical studies that have not provided substantial evidences with regards to the impacts of these factors on capital structure. It 
is important to measure the determinants of capital structure as it could help managers to conduct risk management efficiently. Therefore, this study examines two objectives; firstly, to investigate the determinants of capital structure for each sector among Malaysian Shariah-compliant firms, and whether the inclusion of Islamic debt (leverage 1 and leverage 2) has led to different results due to changes in the screening methodology. Secondly, this study examines the target Capital Structure and Speed of Adjustment for both before and after the Revised Screening Methodology.

This study employs a quantitative approach to collect data from the Thomson Reuters Database. In this study, 192 Shariah-compliant companies in Malaysia were selected from 1999 to 2017. This study applies panel data analysis by using generalized method of moment (GMM). The panel data analysis is examined using STATA software. This paper is organized as follows; the next session presents a literature review on the revised Shariah screening methodology, capital structure and speed of adjustment based on previous research. The following section is the results of the data and model of analysis. The subsequent section presents a discussion on the findings of the research analysis. The last section summarizes the conclusion and discussion of the research.

\section{Literature Review}

\subsection{The Impact of the Revised Screening Methodology}

Shariah-compliant firms in Malaysia are screened based on the benchmarks that have been specified by the SC. The screening methodology was revised by the SC in 2013. The revision not only included operating activities, but also the financing and investing aspects of the listed firms' business operations. The financial ratios were added benchmark indicators in the screening process during the revision of the methodology for firms to be listed as Shariah-compliant. In light of these changes, relevant questions were raised on the effectiveness of the revised screening methodology (Zainudin et al., 2014; Najib et al., 2014; Muhammad, 2015; Suffian et al. (2015); Md. Hashim et al., 2017). Zainudin et al. (2014) revealed that companies with high levels of conventional debt were considerably affected as there were no screening criteria that were based on the total conventional debt of company. Moreover, Muhammad (2015) suggested that after the introduction of the revised screening methodology, the status of firms were affected due to (i) the companies' mixed activities that were previously assessed under the 5, 10, 20, and 25 percent benchmarks, and were subsequently revised to reassess the current firms activities under the 5 and 20 percent benchmarks, and (ii) companies with high conventional debt were affected as there were no previous screening that was based on the total conventional debt of the companies.

Furthermore, a review of the study conducted by Suffian et al. (2015) indicated that some of the Shariah-compliant firms had a high risk of having 
larger debts. Consequently, these results suggest that Shariah-compliant firms should minimise their risk and uncertainties. With regards to the Shariah screening criteria, Najib et al. (2014) concluded that the inclusion of financial ratio benchmarks and restructuring of the business activity benchmarks would enhance the robustness of the screening methodology for the listed Shariahcompliant companies. At the same time, the robustness of the screening methodology would be able to stimulate competitiveness within the Malaysian Islamic equity market and Islamic fund management industries. In accordance with the study conducted by Md. Hashim et al. (2017), the formulas that were applied for the financial ratios in the Shariah-compliance criteria are taken based on the best practice approach, which may or may not concur with most of the current leading Shariah stock screening providers.

\subsection{The Determinants of Capital Structure}

In relation to financial leverage, the existing literature on capital structure are extensive, and mainly highlights the factors that influence capital structure. The causes of capital structure have been studied extensively (Al-Najjar, 2011; AlYahyaee et al., 2013; Antoniou et al., 2002; Bhattacharjee et al., 2010; Bouraoui and Li, 2014; Brendea, 2014; Drobetz et al., 2013; Getzmann et al., 2014; Haron et al., 2013; Haron, 2016; Haron \& Ibrahim, 2011). In the analysis of capital structure, Al-Najjar (2011) suggested that capital structure choices are influenced by institutional ownership, profitability, business risk, asset tangibility, asset liquidity, market-to-book, and firm size. Additionally, it has been concluded that the factors influencing capital structure choice are consistent in both developed and developing countries. Moreover, the study found that Jordanian firms have target capital structure ratios, and were adjusted relatively quickly to the target capital structure.

The study carried out by Antoniou et al. (2002) demonstrated that leverage ratio is positively correlated to the size of the firm. However, the leverage ratio is inversely affected by the market-to-book ratio, term-structure of interest rates, and share price performance. The results indicated different directions and degrees of leverage that have been influenced by fixed-assets ratio, equity market premium, profitability, and effective tax rates. The firm's capital structure were found to be close to the target, with the results showing different speeds in all three countries when the firm's debt ratios were adjusted. The literature further concluded that the capital structure decision is not only based on its own characteristics, but is also influenced by the firm's operating traditions and environment. Similarly, Haron and Ibrahim (2011) have concurred with previous literature that the capital structure decision is not only the product of the firm's own characteristics, but is also a result of the institutional environment and corporate governance in which the firm operates.

Based on econometric analysis, the growth of firms is positively related to the firm's leverage ratio, particularly for IT firms (Bhattacharjee et al., 2010). The authors found that the creditor's rights, maintenance of legal reserves and law 
enforcement, director's rights on borrowing, and risk assessments are important determining factors for the capital structure decision of a firm. Previous studies on target capital structure identified profitability, firm's size, and asset tangibility as the most important determining factors for target capital structure. Conversely, researchers have reported that ownership structure had no significant effect on the target capital structure for Romanian firms. Furthermore, it is observed that the adjustment speed of size is high, and suggested that it is costly to firms when they deviate from the target capital structure.

Based on previous studies, determinants for capital structure decision can be divided into two components; common and industry-based components. In Asia, profitability and tangibility of assets are categorized under common determinants, while industrial median, size, and non-debt tax shield are categorized under industry-based components. The results revealed significant evidences that suggest large Asian companies pursue target capital structures similarly to those in the U.S. and Europe (Getzmann et al., 2014). In a study conducted by Haron (2016), target capital structure and capital structure decision were influenced by firm-specific factors observed within Indonesian firms. Some of the examples of firm-specific factors are profitability, business risk, firm size, liquidity, and share price performance. In addition, the identification of the factors that influence target capital structure and capital structure decision will be able to guide firms toward value maximization.

\subsection{Target Capital Structure on Speed of Adjustment}

Various studies have investigated target capital structure on speed of adjustment (Abdeljawad et al., 2013; Arioglu \& Tuan, 2014; Baxamusa \& Jalal, 2014; Bonaimé et al., 2014; Byoun, 2008; Chan \& Chang, 2008; DeAngelo et al., 2011; Drobetzetal., 2013; Drobetz \& Wanzenried, 2006; Haron et al., 2013; Haron, 2014; Hovakimian \& Li, 2011). In a study on target capital structure, Abdeljawad et al. (2013) found that over-leveraged firms have shown faster adjustment compared to under-leveraged firms. Additionally, firms that are far from the target capital structure have a faster adjustment than those close to the target. This is further supported by Haron et al. (2013), whereby a negative relationship between the speed of adjustment and distance from target leverage was identified. Hence, there is fast adjustment for firms that are far from the target capital structure. The results are consistent with the dynamic trade-off theory. The researchers have also observed that the firms in Malaysia are under-adjusted because the required adjustment will be below the target within a year. Moreover, the study suggested that firm-specific factors (firm size and profitability) have significantly affected the speed of adjustment for firms in Malaysia. The same authors obtained similar results on the speed of adjustment and target capital structure for firms in Thailand. Haron (2014) proposed that property firms do practice target capital structure that influences firm characteristics such as profitability, liquidity, asset 
structure, firm size, non-debt tax shield, and growth opportunity. Property firms are partially adjusted from time to time and supports the dynamic trade-off theory, while the capital structure decisions of property firms are influenced by the pecking order and market timing theories. With regards to the Malaysian Shariah-compliant securities, Haron and Ibrahim (2012) have observed that there exists target capital structure for Shariah-compliant firms in Malaysia, for both firm specific and country-specific factors that have played important roles and are related to the theory (Based on Table 1). The authors have proposed that firms would need to readjust with a faster speed of adjustment in order for firms to be under-adjusted. However, such rapid adjustment towards target leverage suggests the existence of the dynamic trade-off theory. Other than that, Arioglu and Tuan (2014) have concluded that the speed of adjustment is estimated to be approximately $29 \%$. The results for the adjustment speed are in line with the prediction made from the trade-off theory, and have suggested that firms must follow their target capital structures when their leverage ratios deviate from their targets. In a separate study on target capital structure, Baxamusa and Jalal (2014) found that an increase in one percent of a country's Protestant religiosity can decrease 0.4 percent of leverage and frequent debt issuance. The study indicates that religiosity could significantly affect the firms' adjustment speed toward the target capital structure. The study noted that the differences in leverage within the U.S. are similar to the behavior of firms in many Catholic and Protestant countries outside of the U.S.

Numerous studies have been conducted to investigate market reactions on share repurchases and capital structure policy. To further investigate the relationship between stock returns to repurchase announcements and capital structure policy, Bonaimé et al. (2014) carried out a series of experiments. The authors evaluated the benefits of the trade-off theory under levered firms on share repurchase as the repurchased equity enabled firms to move towards the optimal debt ratio. On the other hand, the market timing theory benefited undervalued firms that took advantage of the mispricing opportunities from repurchased equities. Capital structure adjustments that require the repurchasing of overvalued stock have been shown to be less beneficial and more costly.

In a study conducted by Chan and Chang (2008), firm-specific stock return variation is a significant adjustment towards target capital structure. This adjustment supports the trade-off theory for financing decisions in Taiwanese firms. Furthermore, high or low firm-specific stock return variation supports the pecking order and market timing theory. The results suggested that firmspecific stock variation provided an understanding to capital structure decisions. Corporate financing decisions are mostly associated with the efficiency of capital markets. According to Byoun (2008), the speed of adjustment happens when firms have a higher or lower debt, or when firms face a financial surplus or deficit. Thus, the study concluded that firms will move to target capital structures when they experience financial deficits or surplus. 
Table 1. Predicted Signs and Supporting Theories for Each Explanatory Variables

\begin{tabular}{|c|c|c|c|}
\hline No. & Variables & Predicted Sign & Supporting theory \\
\hline 1. & Non-Debt Tax Shield & $\begin{array}{l}(-) \\
(+)\end{array}$ & Static Trade-Off \\
\hline 2. & Tangibility & $\begin{array}{l}(-) \\
(+)\end{array}$ & $\begin{array}{l}\text { Agency Theory } \\
\text { Static Trade-Off }\end{array}$ \\
\hline 3. & Profitability & $\begin{array}{l}(-) \\
(+)\end{array}$ & $\begin{array}{l}\text { Pecking Order } \\
\text { Static Trade-Off }\end{array}$ \\
\hline 4. & Business Risk & $(-)$ & Static Trade-Off \\
\hline 5. & Firm Size & $(-)$ & Static Trade-Off \\
\hline 6. & Growth Opportunities & $\begin{array}{l}(-) \\
(+)\end{array}$ & $\begin{array}{l}\text { Agency Theory } \\
\text { Pecking Order }\end{array}$ \\
\hline 7. & Liquidity & $(-)$ & Pecking Order \\
\hline 8. & Share Price Performance & $(-)$ & Market Timing \\
\hline
\end{tabular}

Source: Haron and Ibrahim (2012)

\section{Data and Model of Analysis}

The sample for this study comprises of 192 Shariah-compliant companies that were listed in Bursa Malaysia from 1999 to 2017. Out of a total of 1087 Shariahcompliant firms that were listed between the years 2007 and 2016, only 200 (including financial sector) Shariah-compliant firms were consistently listed from 2007 to 2016. After the arrangement, 192 firms were then selected to be included into the sample for this study as the data on these firms were fully documented (Refer Table 2). The data was sourced from the Thomson Reuters Database that recorded the company's profile on a annual basis. Listed companies from the financial sector were excluded from the sample (Refer Table 2) due to its exclusive features in financial statements and business activities (Ali, Ibrahim, Mohammad, Zain, \& Alwi, 2009).

Table 2. Structure of the Panel Data

\begin{tabular}{lllr}
\hline No. & Sector & $\begin{array}{l}\text { No. of records on Shariah- } \\
\text { compliant firms maintain for } \\
\text { the 10 years from 2007 until } \\
2016\end{array}$ & No. of observation \\
\hline 1. & Consumer Products & 35 & 665 \\
2. & Industrial Products & 59 & 1121 \\
3. & Construction & 19 & 361 \\
4. & Trading Services & 35 & 665 \\
\hline
\end{tabular}




\begin{tabular}{llcc}
\hline No. & Sector & $\begin{array}{l}\text { No. of records on Shariah- } \\
\text { compliant firms maintain for } \\
\text { the 10 years from 2007 until } \\
2016\end{array}$ & No. of observation \\
\hline 5. & Properties & 16 & 304 \\
6. & Plantation & 18 & 342 \\
7. & Technology & 7 & 133 \\
8. & Infrastructure & 3 & 57 \\
\hline & Total & 192 & 3648 \\
\hline
\end{tabular}

Table 3 presents the variables used in this study with the measurement for each variable. In this study, leverage 1 (Total Conventional Debt to Total Assets) and leverage 2 (Total Debt to Total Assets) were applied as dependent variables. This study used two measurements of leverage, where leverage 1 is defined as Total Conventional Debt to Total Assets and leverage 2 is the Total Debt to Total Assets. The main objective for the calculation of leverage 1 is due to the 33 percent threshold for financial ratio benchmarks that was set by the Securities Commission Malaysia which consists of debt to total assets, where debt only includes conventional debt. Therefore, the calculation of leverage 1 in this study consists of only conventional debt while leverage 2 includes both Islamic debt and conventional debt. Independent variables consist of non-debt tax shield, tangibility, profitability, business risk, firm size, growth opportunities, liquidity, and share price performance. The explanatory variables are firm-specific, and are in line with previous studies (Haron et al., 2013; Haron, 2016; Haron \& Ibrahim, 2011).

Table 3. Variables Used in the Measure of Leverage and Its Explanatory Variables

\begin{tabular}{lll}
\hline No. & Variable & Measurement \\
\hline \multicolumn{2}{l}{ Leverage: } & \\
1. & Leverage 1 (LEV1) & Total Conventional Debt over Total Assets \\
2. & Leverage 2 (LEV2) & Total Debt over Total Assets \\
\hline \multicolumn{2}{l}{ Explanatory Variable: } & \\
1. & Non-Debt Tax Shield (NDTS) & Annual Depreciation Expenses over Total Assets \\
2. & Tangibility (TANG) & Net Fixed Assets over Total Assets \\
3. & Profitability (PROFIT) & EBIT over Total Assets \\
4. & Business Risk (RISK) & Yearly Change of EBIT \\
5. & Firm Size (SIZE) & Natural Logarithm of Total Assets \\
6. & Growth Opportunities & Market Value of Equity to Book Value of Equity \\
& (GROWTH) & \\
7. & Liquidity (LIQUIDITY) & Current Assets over Current Liabilities \\
8. & Share Price Performance (SPP) & First Difference of the Year End Share Price \\
\hline
\end{tabular}


This study employs the panel data method to examine the existence of target capital structure and identify the factors that affect the capital structure for Shariah-compliant firms for each sector. This method allows the elimination of unobservable heterogeneity for each observation in the sample of the study. Panel data analysis was carried out by using Generalised Method of Moment (GMM). The regression models for the panel data must comply with some assumptions; either it is linear, unbiased, lag structure or contained important results prior to testing the model. To examine the determinants of capital structure, this research used the following model:

$$
\begin{aligned}
& \text { LEV }_{\mathrm{i}, \mathrm{t}}=\alpha_{\mathrm{i}, \mathrm{t}}+\beta_{1} \text { NDTS }_{\mathrm{i}, \mathrm{t}}+\beta_{2} \text { TANG }_{\mathrm{i}, \mathrm{t}}+\beta_{3} \text { PROFIT }_{\mathrm{i}, \mathrm{t}}+\beta_{4} \mathrm{RISK}_{\mathrm{i}, \mathrm{t}}+\beta_{5} \mathrm{SIZE}_{\mathrm{i}, \mathrm{t}}+ \\
& \beta_{6} \text { GROWTH }_{\mathrm{i}, \mathrm{t}}+\beta_{7} \text { LIQUIDITY }_{\mathrm{i}, \mathrm{t}}+\beta_{8} \mathrm{SPP}_{\mathrm{i}, \mathrm{t}}+\varepsilon_{\mathrm{i}}
\end{aligned}
$$

where $\mathrm{LEV}_{\mathrm{i}, \mathrm{t}}$ is the leverage ratio of firm ${ }_{\mathrm{i}}$ at time ${ }_{\mathrm{t}}$; NDTS $_{\mathrm{i}, \mathrm{t}}$ is a non-debt tax shield of firm ${ }_{i}$ at time ${ }_{t}$; TANG $_{i, t}$ is the tangibility of firm ${ }_{i}$ at time ${ }_{t}$; PROFIT $_{i, t}$ is the profitability of firm ${ }_{i}$ at time ${ }_{t}$ RISK $_{i, t}$ represents a business risk of firm ${ }_{i}$ at time ${ }_{t} ;$ SIZE $_{i, t}$ is the firm size of firm ${ }_{i}$ at time ${ }_{t}$ GROWTH $_{i, t}$ is the growth opportunities of firm ${ }_{i}$ at time ${ }_{t}$; LIQUIDITY $_{i, t}$ is the liquidity of firm ${ }_{i}$ at time ${ }_{t}$; and $\mathrm{SPP}_{\mathrm{i}, \mathrm{t}}$ is the share price performance of firm ${ }_{\mathrm{i}}$ at time ${ }_{\mathrm{t}}$.

Furthermore, the main advantage of using this model is that it allows for the relationship between non-debt tax shield, tangibility, profitability, business risk, firm size, growth opportunities, liquidity, share price performance, and capital structure to be dynamic in nature. This study uses the GMM estimator proposed by Arellano \& Bond (1991) to investigate the effect of non-debt tax shield, tangibility, profitability, business risk, firm size, growth opportunities, liquidity, and share price performance on capital structure. Thus, the dynamic regression model that incorporated the panels containing many firms and a small number of time periods is presented as follows:

$$
\mathrm{LEV}_{\mathrm{i}, \mathrm{t}}-\mathrm{LEV}_{\mathrm{i}, \mathrm{t}-1}=\delta\left(\mathrm{LEV}^{*}{ }_{\mathrm{i}, \mathrm{t}}-\mathrm{LEV}_{\mathrm{i}, \mathrm{t}-\mathrm{1}}\right)
$$

Therefore, the new dynamic regression model is as follows:

$\mathrm{LEV}^{*}{ }_{\mathrm{i}, \mathrm{t}}=\delta \alpha+(1-\delta) \mathrm{LEV}_{\mathrm{i}, \mathrm{t}-1}+\delta \beta_{1} \mathrm{NDTS}_{\mathrm{i}, \mathrm{t}}+\delta \beta_{2} \mathrm{TANG}_{\mathrm{i}, \mathrm{t}}+\delta \beta_{3} \mathrm{PROFIT}_{\mathrm{i}, \mathrm{t}}+$ $\delta \beta_{4}$ RISK $_{\mathrm{i}, \mathrm{t}}+\delta \beta_{5}$ SIZE $_{\mathrm{i}, \mathrm{t}}+\delta \beta_{6}$ GROWTH $_{\mathrm{i}, \mathrm{t}}+\delta \beta_{7}$ LIQUIDITY $_{\mathrm{i}, \mathrm{t}}+\delta \beta_{8} \mathrm{SPP}_{\mathrm{i}, \mathrm{t}}+\lambda_{\mathrm{i}}+$ $\eta_{\mathrm{t}}+\varepsilon_{\mathrm{it}}$

Whereby, $\delta$ is the adjustment speed that represents the magnitude of adjustment from actual to target capital structure. The $\delta$ is between 0 and 1 . If $\delta_{i, t}=0$, there is no adjustment to the target capital structure. However, when $\delta_{\mathrm{i}, \mathrm{t}}<1$, an adjustment is required to attain the target, while if $\delta_{i, t}>1$, this indicates that the firms are over-adjusted, and therefore requires the necessary adjustments which 
may still not be enough to reach the optimal level. To solve the heterogeneity bias, error terms are denoted as $\lambda_{i}$ and $\eta_{t}$, representing the unobserved individual specific effect (such as firm and time).

\section{Empirical Results}

This section presents the results of the descriptive statistics (Table 4) and estimations for the dynamic regression model using GMM estimations on data sets described above over the period from 1999 to 2017. The results are divided into eight columns, representing the eight sectors (Eight columns are as such: Column 1 (Consumer Products); Column 2 (Industrial Products); Column 3 (Construction); Column 4 (Trading Services); Column 5 (Properties); Column 6 (Plantation); Column 7 (Technology); and Column 8 (Infrastructure)). Table 5 records the GMM results at first different for leverage 1 (Total Conventional Debt to Total Assets), while Table 6 records the GMM results at first different for leverage 2 (Total Debt and Total Assets). Table 7 depicts the impact of target capital structure maturity in speed of adjustment. Table 8 shows the impact on Leverage 1 (Total Conventional Debt to Total Assets) of Revised Screening Methodology. Table 9 presents the impact on Leverage 2 (Total Debt to Total Assets) of Revised Screening Methodology. Lastly, Table 10 presents the summary of Target Capital Structure Maturity in Speed of Adjustment in Implementation of Revised Screening Methodology on Nov 2013.

\subsection{Descriptive Statistics}

Table 4 presents the descriptive statistics such as mean, standard deviation, variance, minimum and maximum for each sector, which are Consumer Products, Industrial Products, Construction, Trading \& Services, Properties, Plantation, Technology and Infrastructure.

The mean for leverage 1, leverage 2, profitability, size of firm and growth opportunities for Infrastructure are 20.12\%, 25.82\%, 10.37\%, 19.46 and $75.53 \%$ respectively. These values are higher than those of other industries such as Consumer Products, Industrial Products, Construction, Trading \& Services, Properties, Plantation and Technology. The Technology sector has the lowest mean for both leverage 1 and leverage 2, which is $9.93 \%$. The lowest average profitability and growth for Trading \& Services sector are 4.14\% and $-515.18 \%$ respectively, while the size of firm under Consumer Products is 15.91. The minimum for leverage 1 of the Infrastructure sector is $0 \%$ and its maximum is $63.32 \%$, while its standard deviation is at $21.26 \%$. The minimum for leverage 1 of the Technology sector is $0 \%$ and its maximum is $41.99 \%$, while the standard deviation is $11.46 \%$. This indicates that the leverage 1 for Infrastructure is more volatile than Technology. On the other hand, the minimum for leverage 2 of 
Infrastructure is $0 \%$ and its maximum is $66.06 \%$, while the standard deviation is at $23.86 \%$. The minimum for leverage 2 of Technology is $0 \%$ and its maximum is $41.99 \%$, while the standard deviation is $11.46 \%$. This indicates that leverage 2 for Infrastructure is more volatile than Technology.

Additionally, the minimum and maximum profitability for Infrastructure are $-44.83 \%$ and $62.07 \%$ respectively, while the minimum and maximum profitability for Trading \& Services are $-248.91 \%$ and $37.83 \%$ respectively. The profitability for Infrastructure is more volatile with a standard deviation of $18.36 \%$, compared to Trading \& Services that has a standard deviation of $14.16 \%$. The minimum growth opportunities for Infrastructure is $0 \%$ with its maximum at $107.784 \%$, while the standard deviation is $201.34 \%$. The growth opportunities for Trading \& Services has a minimum of $-36182.71 \%$ and a maximum of $182.856 \%$, with a standard deviation of $1403.274 \%$. In contrast to profitability, the growth opportunities for Infrastructure is less volatile than Trading \& Services. The minimum and maximum values for size of firm of Infrastructure are $0 \%$ and $22.52 \%$ respectively, while the minimum and maximum values for size of firm of Consumer products are $0 \%$ and $23.63 \%$ respectively. The size of firm for Infrastructure is less volatile with a standard deviation of 6.7435 , as compared to Consumer products that has a standard deviation of 7.5248.

The highest average business risk under Consumer product is $159.067 \%$, while the lowest average business risk for Trading \& Services is $-1571.13 \%$. The minimum business risk for Consumer product is $-679.857 \%$ and the maximum is $4726.667 \%$, while the standard deviation is $186.214 \%$. The business risk for Trading \& Services has a minimum of $-1046880 \%$ and a maximum of $738.41 \%$, while the standard deviation is at $40596.42 \%$. This indicates that the business risk for Consumer product is less volatile than Trading \& Services.

The average Non-Debt Tax Shield (NDTS) for Properties is $-0.05 \%$, which is higher than those from the other industries (Consumer Products, Industrial Products, Construction, Trading \& Services, Plantation, Technology and Infrastructure). Conversely, the Infrastructure sector has the lowest average NDTS which is $-5.14 \%$. The minimum and maximum NDTS for Properties are $-1.01 \%$ and $0 \%$ respectively, while the minimum and maximum NDTS for Infrastructure are $-33.13 \%$ and $0 \%$ respectively. The standard deviation for NDTS of Properties $(0.15 \%)$ indicates that this sector is less volatility when compared to Infrastructure (7.57\%). In addition, the averages for the tangibility and liquidity of Plantation are $52.49 \%$ and $295.49 \%$ respectively, which are lower than the values for Properties (tangibility) and Infrastructure (liquidity) respectively. The minimum and maximum tangibility values for Plantation are $0 \%$ and $94.21 \%$ respectively, while the minimum and maximum tangibility values for Properties are $0 \%$ and $70.94 \%$ respectively. The standard deviation for tangibility of Plantation is $28.03 \%$, while the standard deviation value for Properties is $16.79 \%$. This suggests that the tangibility for Plantation are more volatile than Properties. Similarly, the minimum, maximum and standard 
deviation of liquidity for Plantation ( $0 \%, 641.519 \%$ and $639.24 \%$ respectively) imply that this sector is more volatile than Infrastructure $(0 \%, 459.09 \%$ and $116.13 \%$ respectively). Finally, the average share price performance (SPP) for Technology is $18.91 \%$, which is higher than Properties with a value of $8.47 \%$. The minimum SPP for Technology is $-82.03 \%$, with a maximum at $384.8 \%$ and standard deviation at $74.13 \%$. On the other hand, Properties has a minimum SPP of $-83.96 \%$, a maximum SPP of $174.28 \%$ and a standard deviation of $43.35 \%$. This indicates that the SPP for Technology is more volatile than Properties.

Based on the descriptive statistic, the preliminary observation suggests that the Infrastructure sector poses higher leverage with higher debt ratios than the other sectors. However, due to the high debt, the profitability, size of firm and business growth are higher and consistent than the other sectors. The results reveal that the large firms tend to raise higher capital with greater business risk which tends to generate larger profitability. Additionally, most of the variables indicate that variance is higher within standard deviation, as compared to between standard deviations. This further implies that the time series variation is more dominant than the cross-sectional variation. Therefore, the use of the panel estimation method is applicable to this research. In addition, the results for the mean of leverage 1 (Total Conventional Debt to Total Assets) and leverage 2 (Total Debt to Total Assets) for all sectors is less than 33 percent of the financial benchmarks set by the Security Commission Malaysia (SC), and subsequently validates that all firms for each sector has fulfilled the requirements by the SC to be listed as Shariah-compliant firm.

Table 4. Descriptive Statistics

\begin{tabular}{lcccccc}
\hline Variables & Mean & $\begin{array}{c}\text { Overall } \\
\text { Standard } \\
\text { deviation }\end{array}$ & $\begin{array}{c}\text { Between } \\
\text { Standard } \\
\text { deviation }\end{array}$ & $\begin{array}{c}\text { Within } \\
\text { Standard } \\
\text { deviation }\end{array}$ & Minimum & Maximum \\
\hline 1) CONSUMER PRODUCTS & & & & & \\
\hline LEV1 & 0.1276 & 0.1368 & 0.1040 & 0.0905 & 0.0000 & 0.6191 \\
LEV2 & 0.1299 & 0.1380 & 0.1048 & 0.0914 & 0.0000 & 0.6191 \\
NTDS & -0.0088 & 0.0183 & 0.0150 & 0.0108 & -0.0960 & 0.0000 \\
TANG & 0.3351 & 0.2254 & 0.1452 & 0.1741 & 0.0000 & 0.9377 \\
PROFIT & 0.0778 & 0.0803 & 0.0478 & 0.0651 & -0.7108 & 0.3517 \\
RISK & 0.5364 & 18.6214 & 3.9544 & 18.2083 & -67.9857 & 472.6667 \\
SIZE & 15.9067 & 7.5248 & 2.8654 & 6.9738 & 0.0000 & 23.6261 \\
GROWTH & 0.0586 & 0.3231 & 0.1841 & 0.2672 & 0.0000 & 6.8471 \\
LIQUIDITY & 2.6080 & 3.0841 & 2.4004 & 1.9764 & 0.0000 & 23.2557 \\
SPP & 0.0913 & 0.3852 & 0.0805 & 0.3770 & -0.7458 & 2.5797 \\
\hline
\end{tabular}




\begin{tabular}{|c|c|c|c|c|c|c|}
\hline Variables & Mean & $\begin{array}{c}\text { Overall } \\
\text { Standard } \\
\text { deviation }\end{array}$ & $\begin{array}{l}\text { Between } \\
\text { Standard } \\
\text { deviation }\end{array}$ & $\begin{array}{c}\text { Within } \\
\text { Standard } \\
\text { deviation }\end{array}$ & Minimum & Maximum \\
\hline \multicolumn{7}{|c|}{ 2) INDUSTRIAL PRODUCTS } \\
\hline LEV1 & 0.1715 & 0.2021 & 0.1049 & 0.1732 & 0.0000 & 2.8224 \\
\hline LEV2 & 0.1744 & 0.2032 & 0.1065 & 0.1735 & 0.0000 & 2.8224 \\
\hline NTDS & -0.0062 & 0.0148 & 0.0125 & 0.0081 & -0.0918 & 0.0000 \\
\hline TANG & 0.3726 & 0.2199 & 0.1397 & 0.1707 & 0.0000 & 0.9750 \\
\hline PROFIT & 0.0555 & 0.0821 & 0.0426 & 0.0704 & -0.6320 & 0.8501 \\
\hline RISK & -0.2055 & 5.3301 & 1.4787 & 5.1244 & -138.8327 & 34.4225 \\
\hline SIZE & 17.4245 & 6.6628 & 2.5109 & 6.1798 & 0.0000 & 23.5299 \\
\hline GROWTH & 0.0833 & 0.5556 & 0.1379 & 0.5385 & -15.6658 & 3.0995 \\
\hline LIQUIDITY & 2.2308 & 2.5465 & 1.5273 & 2.0468 & 0.0000 & 26.7954 \\
\hline SPP & 0.1464 & 0.7854 & 0.1421 & 0.7727 & -0.8832 & 14.6000 \\
\hline \multicolumn{7}{|c|}{ 3) CONSTRUCTION } \\
\hline LEV1 & 0.1519 & 0.1477 & 0.0977 & 0.1129 & 0.0000 & 0.6844 \\
\hline LEV2 & 0.1574 & 0.1504 & 0.1006 & 0.1141 & 0.0000 & 0.6844 \\
\hline NTDS & -0.0012 & 0.0042 & 0.0025 & 0.0034 & -0.0354 & 0.0000 \\
\hline TANG & 0.1575 & 0.1354 & 0.0976 & 0.0964 & 0.0000 & 0.7997 \\
\hline PROFIT & 0.0516 & 0.0952 & 0.0419 & 0.0859 & -0.4725 & 1.1042 \\
\hline RISK & -0.2751 & 6.7087 & 1.5190 & 6.5433 & -119.2114 & 33.5026 \\
\hline SIZE & 17.4614 & 7.0204 & 3.0796 & 6.3464 & 0.0000 & 23.7627 \\
\hline GROWTH & 0.0438 & 0.0876 & 0.0543 & 0.0698 & -0.2506 & 0.6010 \\
\hline LIQUIDITY & 1.7516 & 1.2221 & 0.8009 & 0.9402 & 0.0000 & 8.5722 \\
\hline SPP & 0.1061 & 0.5654 & 0.1068 & 0.5558 & -0.8317 & 4.7917 \\
\hline \multicolumn{7}{|c|}{ 4) TRADING AND SERVICES } \\
\hline LEV1 & 0.1876 & 0.2347 & 0.1071 & 0.2096 & 0.0000 & 3.4515 \\
\hline LEV2 & 0.1969 & 0.2368 & 0.1126 & 0.2092 & 0.0000 & 3.4515 \\
\hline NTDS & -0.0074 & 0.0196 & 0.0184 & 0.0072 & -0.1019 & 0.0000 \\
\hline TANG & 0.3322 & 0.2387 & 0.1700 & 0.1699 & 0.0000 & 0.9260 \\
\hline PROFIT & 0.0414 & 0.1416 & 0.0656 & 0.1260 & -2.4891 & 0.3783 \\
\hline RISK & -157.113 & 4059.642 & 931.3978 & 3954.328 & -104688 & 73.841 \\
\hline SIZE & 18.5554 & 6.7675 & 2.9176 & 6.1251 & 0.0000 & 25.6129 \\
\hline GROWTH & -5.1518 & 140.3274 & 32.2427 & 136.6761 & -3618.271 & 18.2856 \\
\hline LIQUIDITY & 2.2058 & 7.4910 & 2.5230 & 7.0656 & 0.0000 & 154.4811 \\
\hline SPP & 0.1546 & 1.9363 & 0.4246 & 1.890427 & -0.9070 & 48.2491 \\
\hline
\end{tabular}




\begin{tabular}{|c|c|c|c|c|c|c|}
\hline Variables & Mean & $\begin{array}{c}\text { Overall } \\
\text { Standard } \\
\text { deviation }\end{array}$ & $\begin{array}{l}\text { Between } \\
\text { Standard } \\
\text { deviation }\end{array}$ & $\begin{array}{c}\text { Within } \\
\text { Standard } \\
\text { deviation }\end{array}$ & Minimum & Maximum \\
\hline \multicolumn{7}{|c|}{ 5) PROPERTIES } \\
\hline LEV1 & 0.1836 & 0.1449 & 0.0893 & 0.1162 & 0.0000 & 0.7516 \\
\hline LEV2 & 0.1866 & 0.1461 & 0.0922 & 0.1156 & 0.0000 & 0.7516 \\
\hline NTDS & -0.0005 & 0.0015 & 0.0012 & 0.0010 & -0.0101 & 0.0000 \\
\hline TANG & 0.1255 & 0.1679 & 0.1311 & 0.1096 & 0.0000 & 0.7094 \\
\hline PROFIT & 0.0440 & 0.0624 & 0.0372 & 0.0509 & -0.1654 & 0.3452 \\
\hline RISK & 0.0050 & 4.6680 & 1.0683 & 4.5515 & -18.3245 & 70.3846 \\
\hline SIZE & 17.8796 & 6.5083 & 2.0309 & 6.2031 & 0.0000 & 22.6127 \\
\hline GROWTH & 0.6620 & 3.0017 & 2.1379 & 2.1705 & 0.0000 & 28.8765 \\
\hline LIQUIDITY & 2.2508 & 2.1443 & 1.4980 & 1.5771 & 0.0000 & 15.2700 \\
\hline SPP & 0.0847 & 0.4335 & 0.0667 & 0.42870 & -0.8396 & 1.7428 \\
\hline \multicolumn{7}{|c|}{ 6) PLANTATION } \\
\hline LEV1 & 0.1285 & 0.1567 & 0.0869 & 0.1319 & 0.0000 & 0.9104 \\
\hline LEV2 & 0.1391 & 0.1638 & 0.0923 & 0.1370 & 0.0000 & 0.9104 \\
\hline NTDS & -0.0023 & 0.0081 & 0.0069 & 0.0044 & -0.0489 & 0.0019 \\
\hline TANG & 0.5249 & 0.2803 & 0.1141 & 0.2574 & 0.0000 & 0.9421 \\
\hline PROFIT & 0.0604 & 0.0936 & 0.0448 & 0.0829 & -0.9916 & 0.3595 \\
\hline RISK & 0.0179 & 9.3566 & 2.1168 & 9.1270 & -128.8638 & 99.8636 \\
\hline SIZE & 17.7559 & 7.17912 & 2.9795 & 6.5674 & 0.0000 & 23.7693 \\
\hline GROWTH & 0.1028 & 0.3479 & 0.2445 & 0.2538 & 0.0000 & 3.9792 \\
\hline LIQUIDITY & 2.9549 & 6.3924 & 3.7600 & 5.2413 & 0.0000 & 64.1519 \\
\hline SPP & 0.1068 & 0.3467 & 0.0510 & 0.3432 & -0.6376 & 1.6452 \\
\hline \multicolumn{7}{|c|}{ 7) TECHNOLOGY } \\
\hline LEV1 & 0.0993 & 0.1146 & 0.0684 & 0.0954 & 0.0000 & 0.4199 \\
\hline LEV2 & 0.0993 & 0.1146 & 0.0684 & 0.0954 & 0.0000 & 0.4199 \\
\hline NTDS & -0.0170 & 0.0318 & 0.0293 & 0.0164 & -0.1113 & 0.0000 \\
\hline TANG & 0.3963 & 0.2400 & 0.1843 & 0.1681 & 0.0000 & 0.89512 \\
\hline PROFIT & 0.0569 & 0.0909 & 0.0421 & 0.0820 & -0.3978 & 0.2719 \\
\hline RISK & -0.2383 & 2.9761 & 0.5339 & 2.9345 & -16.4397 & 17.772 \\
\hline SIZE & 16.7523 & 7.1421 & 3.2935 & 6.4530 & 0.0000 & 21.4112 \\
\hline GROWTH & 0.1197 & 0.1667 & 0.1014 & 0.1375 & 0.0000 & 0.7528 \\
\hline LIQUIDITY & 1.7608 & 1.2648 & 0.6531 & 1.1097 & 0.0000 & 5.9838 \\
\hline SPP & 0.1891 & 0.7413 & 0.1304 & 0.7313 & -0.8203 & 3.848 \\
\hline
\end{tabular}




\begin{tabular}{lcccccc}
\hline Variables & Mean & $\begin{array}{c}\text { Overall } \\
\text { Standard } \\
\text { deviation }\end{array}$ & $\begin{array}{c}\text { Between } \\
\text { Standard } \\
\text { deviation }\end{array}$ & $\begin{array}{c}\text { Within } \\
\text { Standard } \\
\text { deviation }\end{array}$ & Minimum & Maximum \\
\hline 8) INFRASTRUCTURE & & & & & \\
\hline LEV1 & 0.2012 & 0.2126 & 0.1509 & 0.1725 & 0.0000 & 0.6332 \\
LEV2 & 0.2582 & 0.2386 & 0.2440 & 0.1285 & 0.0000 & 0.6606 \\
NTDS & -0.0514 & 0.0757 & 0.0738 & 0.0451 & -0.3313 & 0.0000 \\
TANG & 0.2623 & 0.2962 & 0.2909 & 0.1740 & 0.0000 & 0.8291 \\
PROFIT & 0.1037 & 0.1836 & 0.1527 & 0.1338 & -0.4483 & 0.6207 \\
RISK & 0.4184 & 3.5055 & 1.0575 & 3.3956 & -14.1735 & 18.0918 \\
SIZE & 19.4600 & 6.7435 & 1.0639 & 6.6863 & 0.0000 & 22.5233 \\
GROWTH & 0.7553 & 2.0134 & 0.8599 & 1.8847 & 0.0000 & 10.7784 \\
LIQUIDITY & 1.5592 & 1.1613 & 0.9932 & 0.8241 & 0.0000 & 4.5909 \\
SPP & 0.1596 & 0.3709 & 0.0883 & 0.3637 & -0.6755 & 1.1867 \\
\hline
\end{tabular}

\subsection{Determinants of Leverage 1 (Total Conventional Debt to Total Assets) and Leverage 2 (Total Debt to Total Assets)}

From the results of the dynamic regression model, the error terms are assumed to be independent and homoscedastic across companies and over time. Specifically, the estimated coefficient of lagged leverage 1 (Total Conventional Debt to Total Assets) is significant at 1 and 5 percent significance level for all sectors (refer Table 5 and 6). These results assert that the model is a dynamic model. Moreover, the lagged dependent variables (lagged leverage 1 and leverage 2) have positive significance, with the speed of adjustment deduced to be approximately 2 years. This concludes that Shariah-compliant firms close approximately $30 \%$ to $70 \%$ of the gap between current and target capital structure within one year (refer table 7). Therefore, it is beneficial for firms to get closer to the target capital structure in order to grow faster at a maximum rate without changes in financial leverage.

Using the one-step system GMM results, for NTDS, only Consumer Products, Trading \& Services, and Properties (column 1, 4, and 5) are significant at 1 percent and 10 percent significance level. NTDS is positively significant at 1 percent for the Consumer Products sector, however it is negatively significant to the leverage for Trading Services and Properties. The negative effect is due to the static trade-off, whereby firms with a higher NTDS than cash flow expected will be able to reduce their debt in the capital structure. The results are similar to both leverage 1 (Total Conventional Debt to Total Assets) and leverage 2 (Total Debt to Total Assets). With regards to tangibility, both leverage 1 (Total Conventional Debt to Total Assets) and leverage 2 (Total Debt to Total Assets) have the same results. Nonetheless, tangibility has a positive effect on leverage for Consumer Products, Trading Services, and Properties. For the Technology sector, tangibility has a negative effect on leverage. The positive relationship 


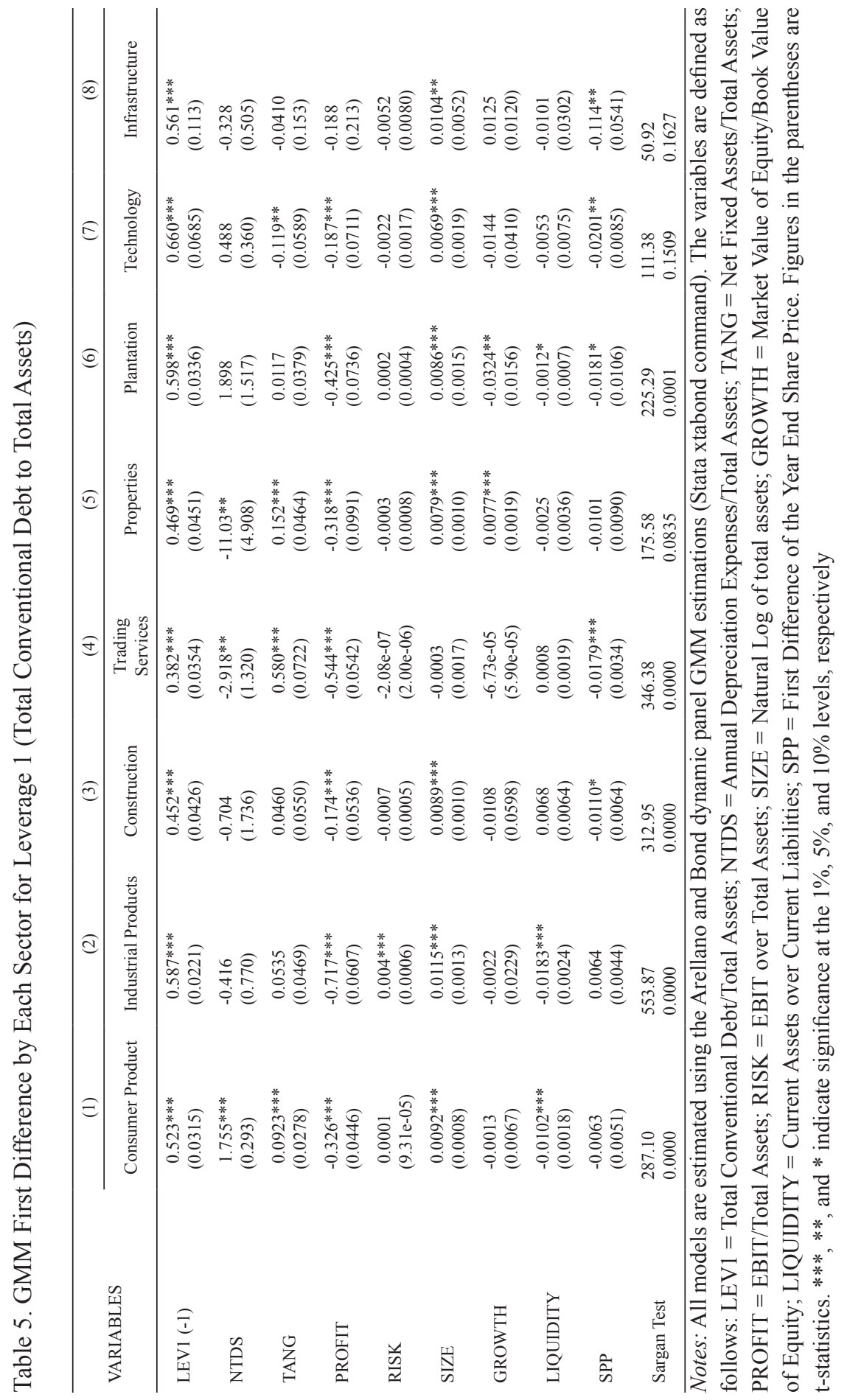




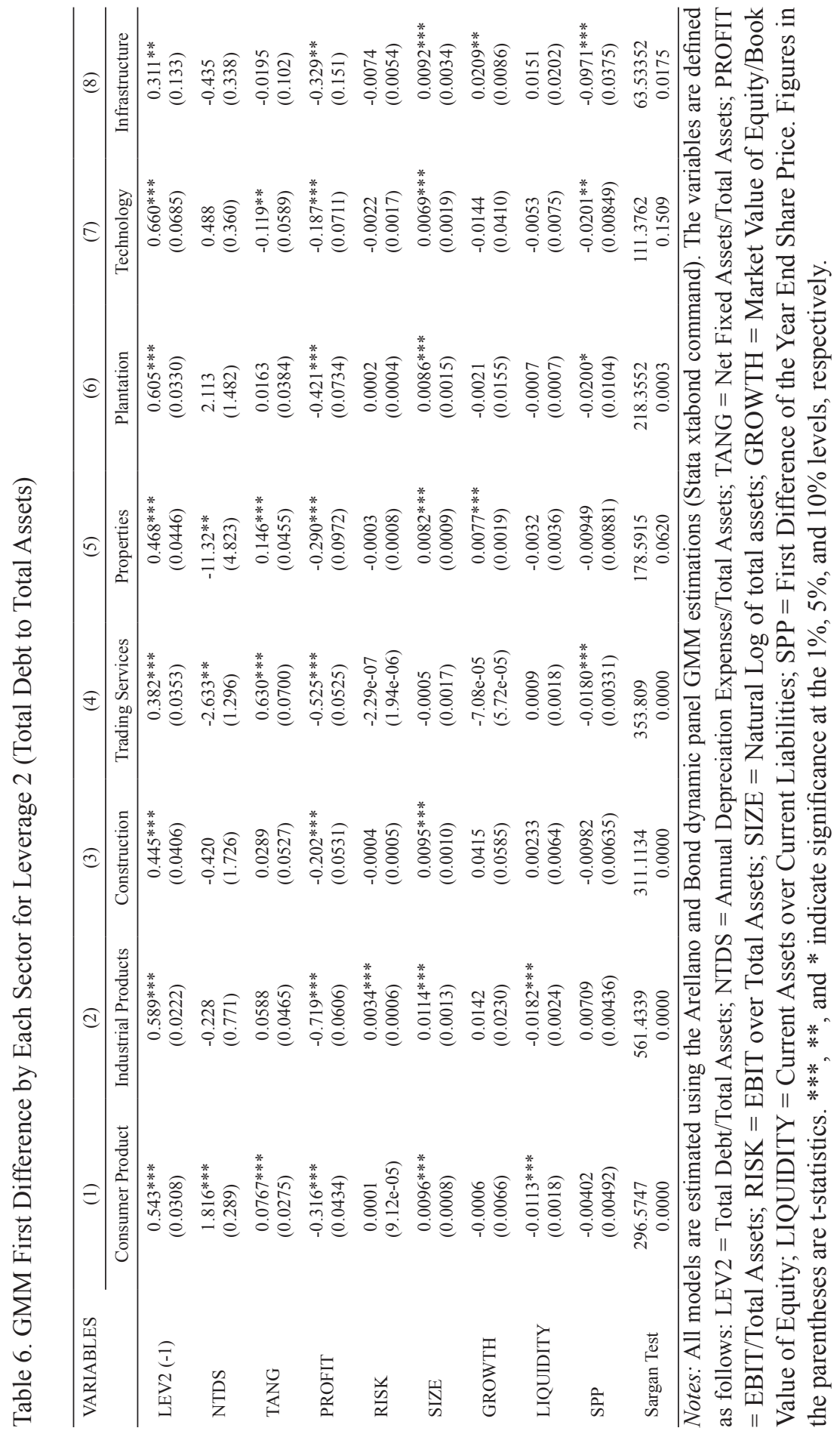




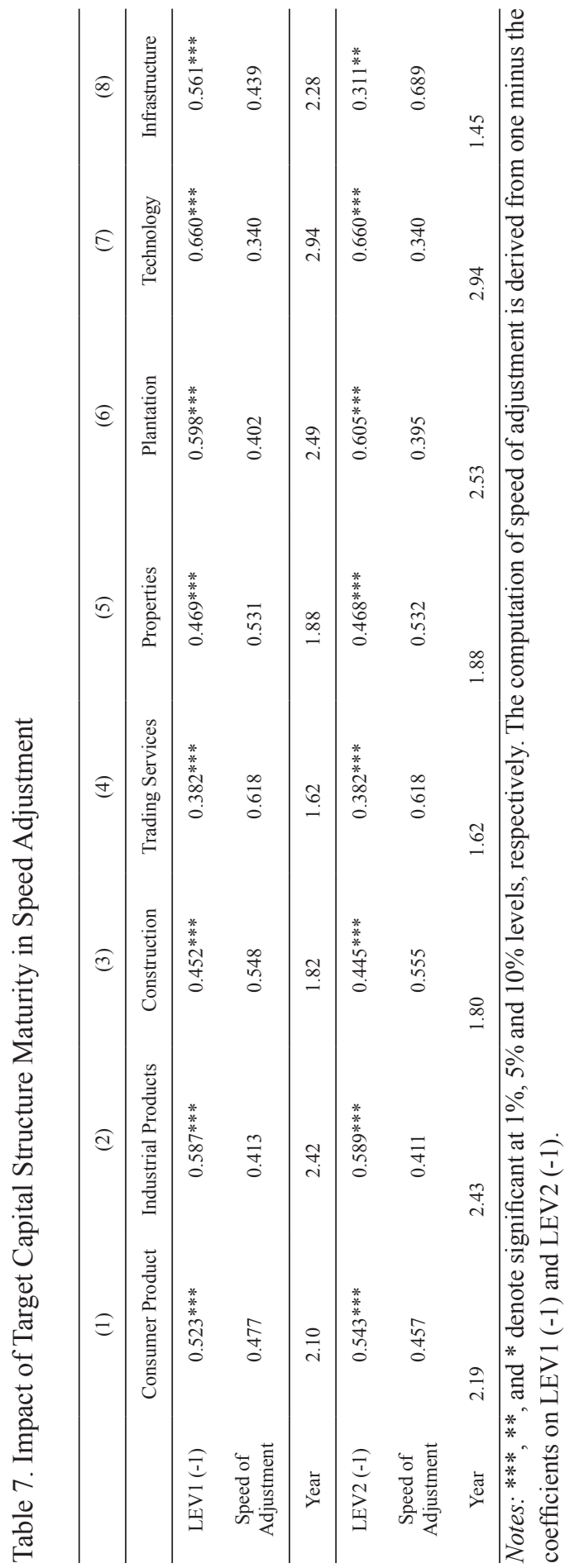


indicates that the firms must have asset-backed debts, whereby debt must be lower than tangible assets for a firm to operate based on Islamic principles. These results comply with the trade-off theory.

This study identified a negative relationship between profitability and leverage for Shariah-compliant firms for all sectors. The result is analogous to a previous study conducted on Malaysian Shariah-compliant securities (Haron and Ibrahim, 2012). This suggests that Shariah-compliant firms with high profitability will use lower leverages in their financial activities. Similarly, firm size for leverage 1 (Total Conventional Debt to Total Assets) and leverage 2 (Total Debt to Total Assets) have the same results, for which firm size has a positive significant relationship to leverage. The results indicate that bigger firms will tend to generate more income and profit, however these firms would require more debt to support their investment activities. Hence, these findings strongly support the pecking order theory. On the other hand, only several sectors have indicated a relationship between growth and leverage (leverage 1 and leverage 2). Higher growth causes firms to raise more leverage, and vice versa. Similarly, there are some sectors (leverage 1: Consumer Products, Industrial Products, and Plantation; leverage 2: Consumer Products, and Industrial Products) where liquidity has a negative relationship to leverage. This negative relationship supports the pecking order theory, for which liquidity of a firm should be negatively associated with leverage. Moreover, the negative relationship between liquidity and leverage shows that firms with highly liquid assets will be able to incur more debt that would enable the firms to continue to run their business. Share price performance is found to have a negative impact on leverage which implies that firms will issue equity to debt when the firm's share price increases. This result supports the market timing theory.

\subsection{Target Capital Structure and Speed of Adjustment, before and after Revised Screening Methodology}

Table 8 records the results of the target capital structure based on two scenarios, where the first scenario is before the revised screening methodology (year 19992013) and the second scenario is after the implementation of the new screening methodology (year 2014-2017). From the year 2014 to 2017, the estimated coefficient for the target leverage 1 (Total Conventional Debt to Total Assets) is significant at the 1 percent significance level for all sectors. This indicates that the target leverage 1 (Total Conventional Debt to Total Assets) was present within the Malaysian Shariah-compliant firms for all sectors. Moreover, it was identified that all sectors adjust at a speed of approximately 0.3 to 0.7 to achieve long-term target leverage. The speed of adjustment can be explained as how quickly firms converge to the target capital structure from their current capital structure (Haron \& Ibrahim, 2012). From the results, it is deduced that the speed of adjustment would take approximately 2 years for firms to achieve the target leverage from their current leverage (refer table 10). After the implementation 


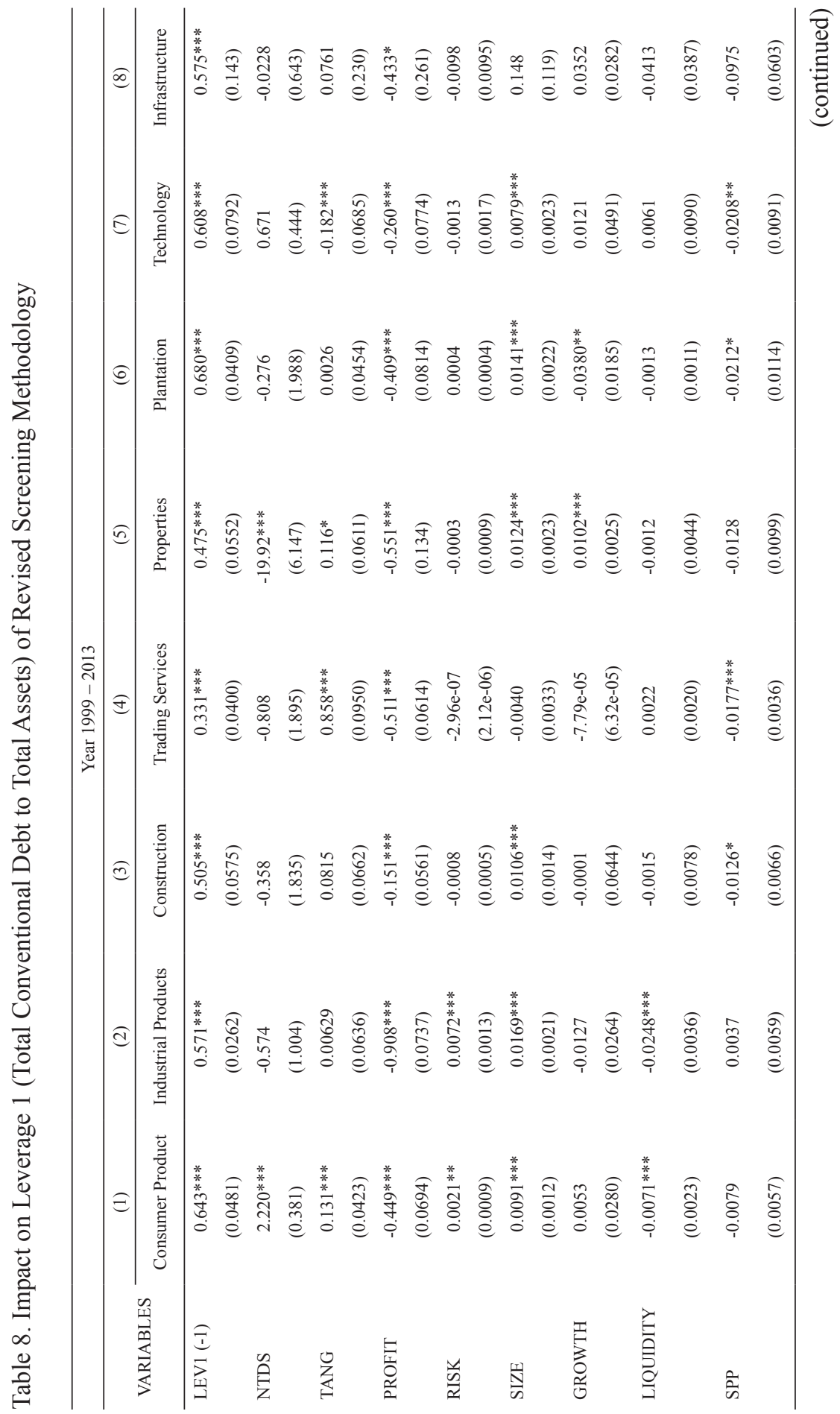




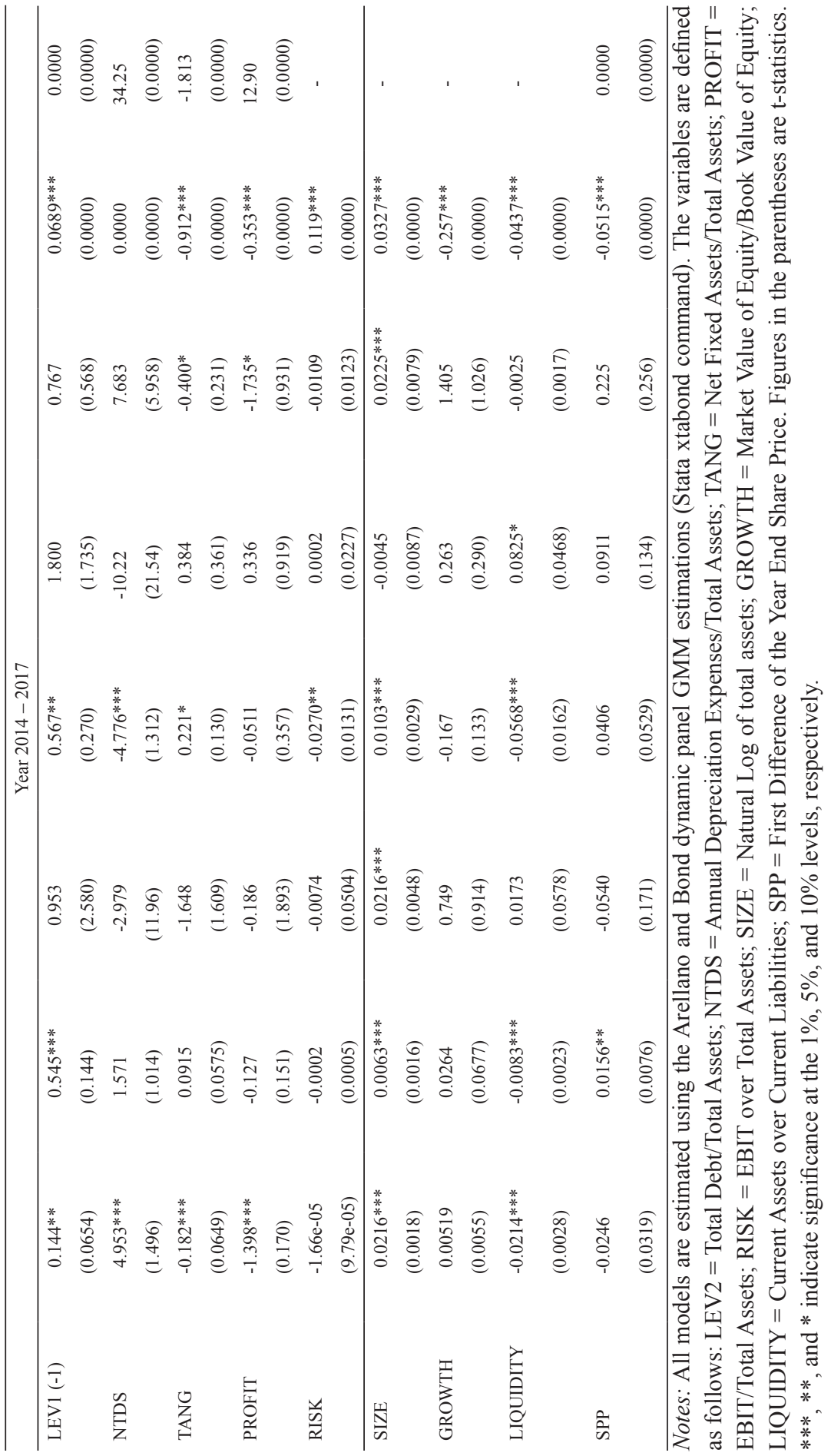


of the new screening methodology (from the year 2014 to 2017), there are only four sectors (sector 1 (Consumer Products), 2 (Industrial Products), 4 (Trading Services) and 7 (Technology) that have significant results at the $1 \%$ and $5 \%$ significance level of the estimated coefficient for the target leverage 1 (Total Conventional Debt to Total Assets). Furthermore, the speed of adjustment is approximately 0.4 to 0.9 , and would take roughly 1 to 2 years for firms to reach the target leverage.

Table 9 shows all sectors from the year 1999 to 2013 for the Malaysian Shariah-compliant firms to achieve the target leverage 2 (Total Debt to Total Assets). The speed of adjustment to reach the target leverage is approximately 0.3 to 0.7 . Moreover, it takes about 1 to 3 years for all sectors to achieve the target leverage level. From the year 2014 to 2017, the results for leverage 1 (Total Conventional Debt to Total Assets) are significant for the sectors $1,2,4$, and 7 , whereby the results are at the $1 \%$ and $5 \%$ significance level for the speed of adjustment to target leverage 2 (Total Debt to Total Assets). The Malaysian Shariah-compliant firms would take around 1 to 2 years to achieve target leverage 2 (Total Debt to Total Assets) from the firms current leverage. This concludes that the Malaysian Shariah-compliant firms for all sectors close approximately $30 \%$ to $70 \%$ of the gap between current and target leverage of leverage 1 (Total Conventional Debt to Total Assets) and leverage 2 (Total Debt to Total Assets) from the year 1999 to 2013 (before the revised screening methodology was introduced). However, from the year 2014 to 2017, only a few sectors reached the target leverage (after the revised screening methodology was introduced). This suggests that the speed of adjustment for Malaysian Shariah-compliant firms to achieve the target leverage from their current leverage was substantially affected when the Securities Commission Malaysia (SC) revised the screening methodology in 2013. Based on Table 10 , the findings imply that after the implementation of the revised screening methodology in November 2013, the speed of adjustment improved. The revised screening methodology led to faster adjustment to the target leverage level. As can be observed in the Consumer Products sector, the speed of adjustment improved from approximately 2 years (year 1999-2013) to 1 year (2014-2017). In addition, the level of conventional debt was found to be lower after the introduction of the revised screening methodology. 


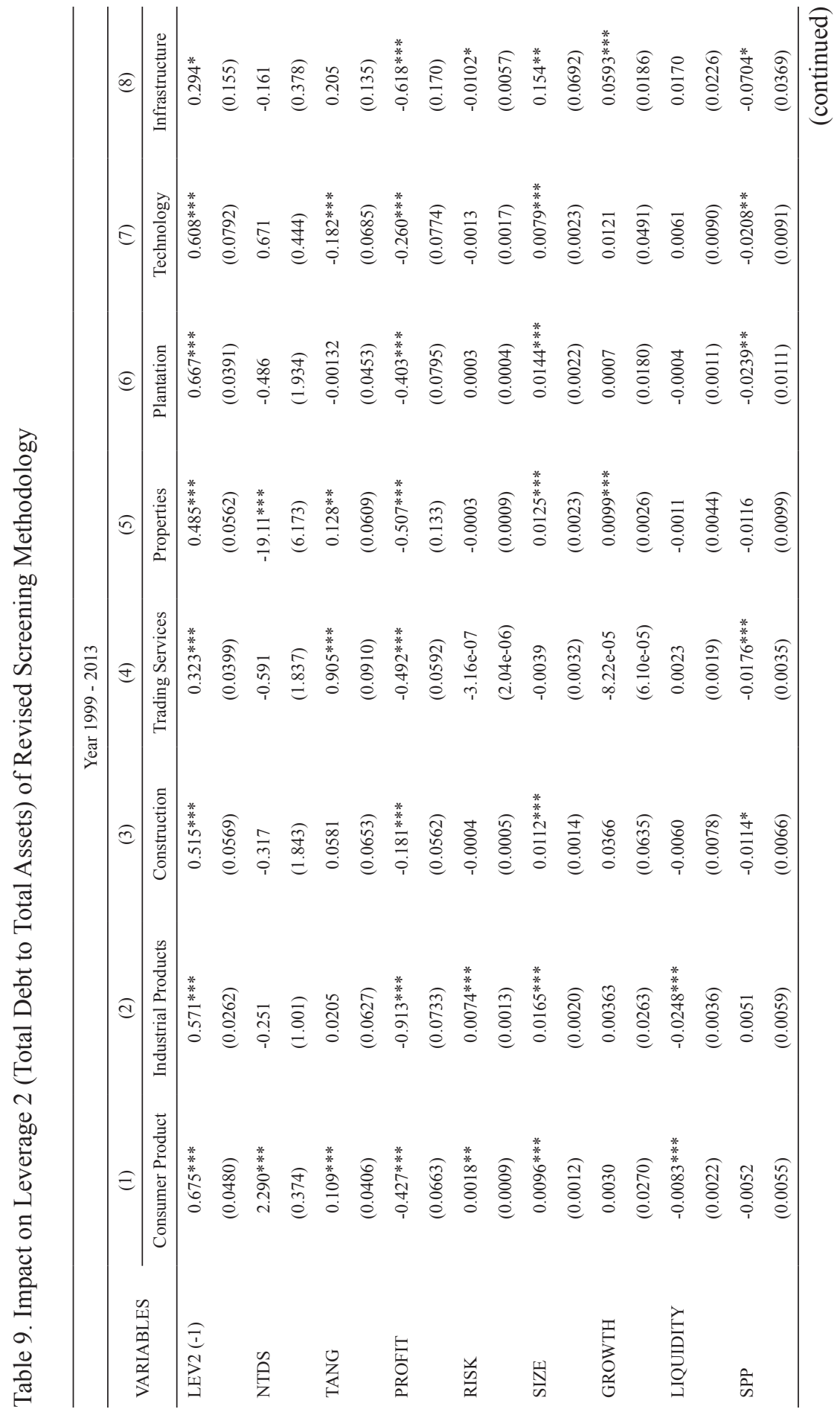




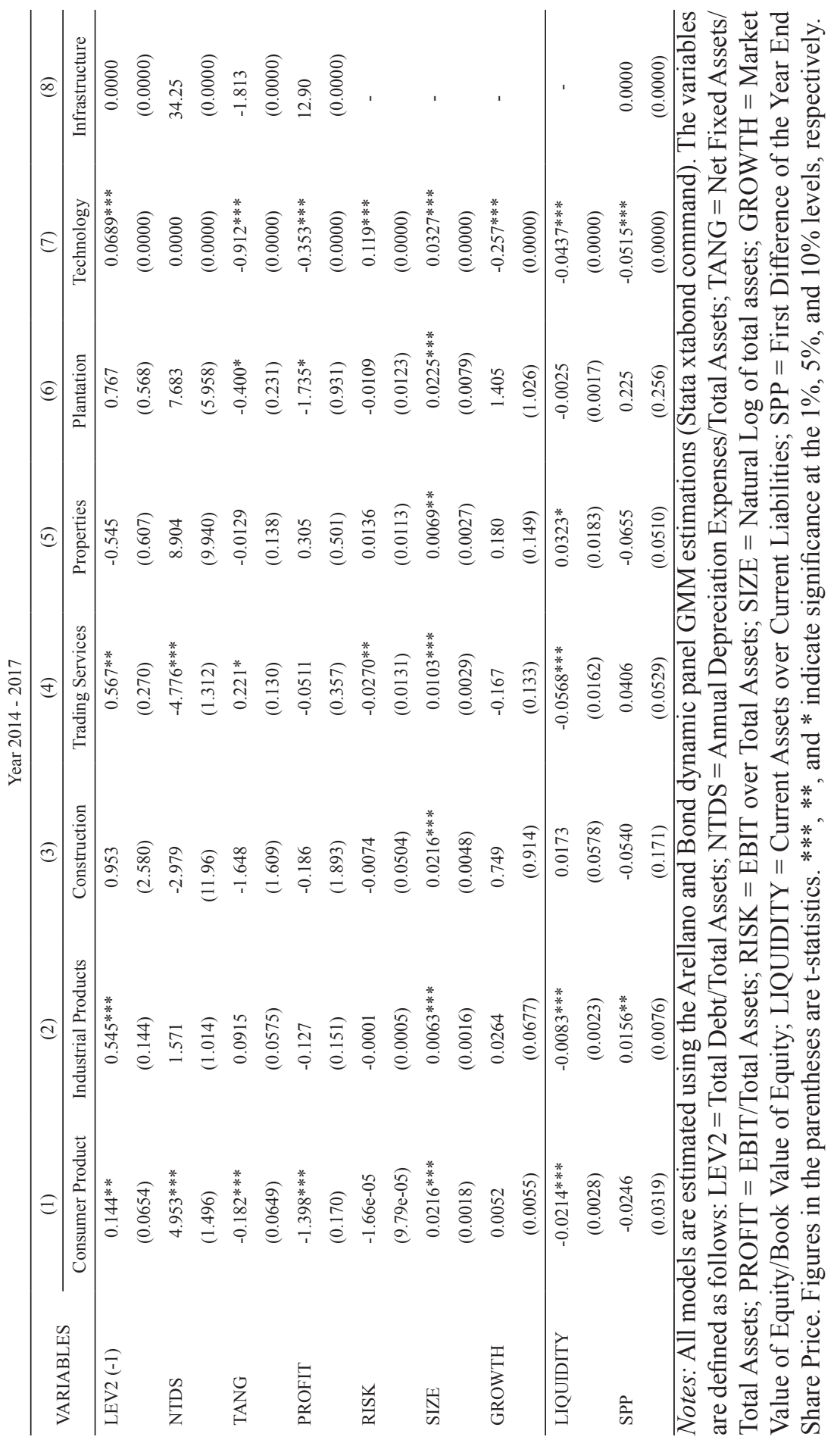




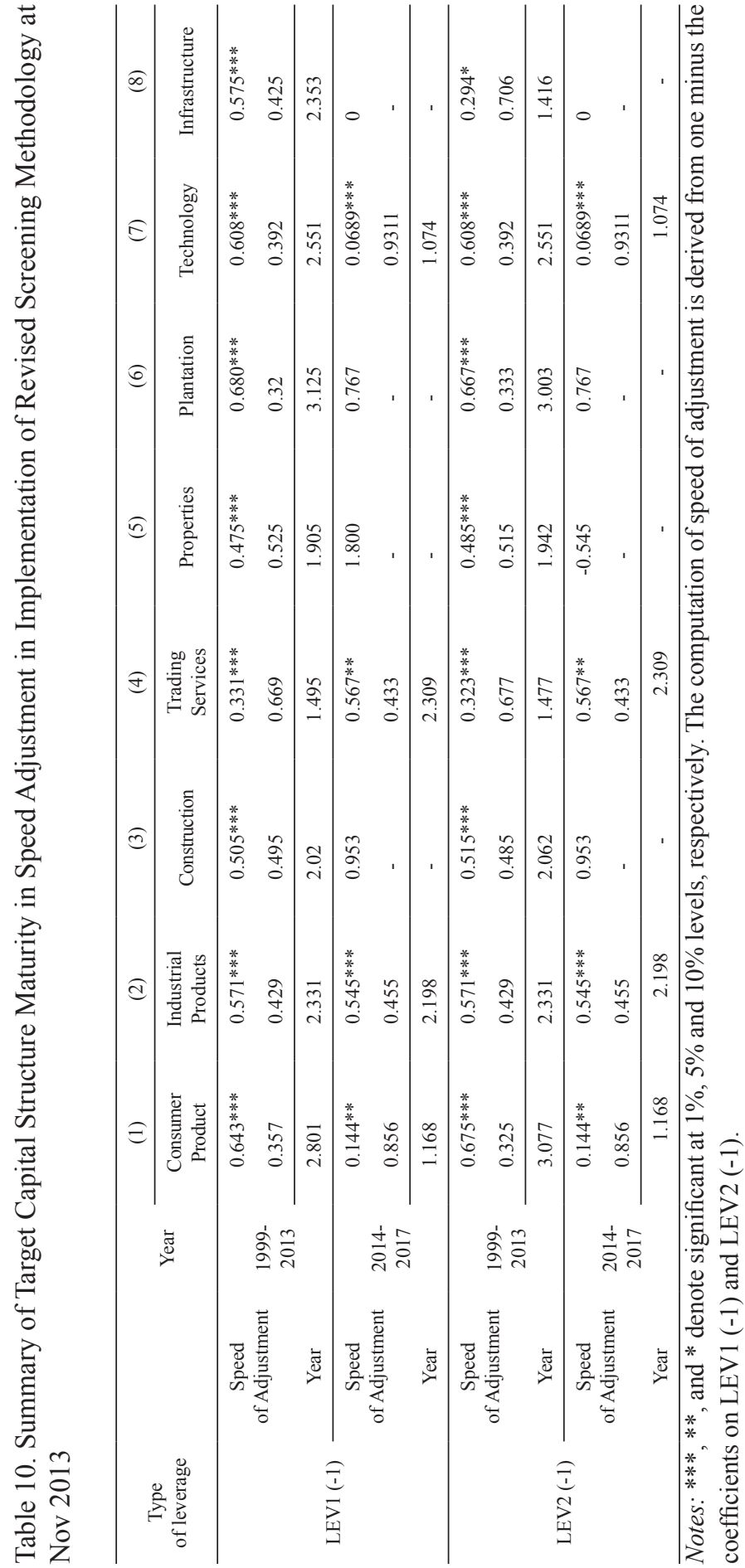




\section{Conclusion and Discussion}

The main objectives for this study are to examine the determinants of capital structure for each sectors among Malaysian Shariah-compliant firms, and whether the inclusion of Islamic debt (leverage 1 and leverage 2) has led to different results due to changes in the screening methodology. This study seeks to investigate the motive behind the reduced number of Shariah-compliant firms in November 2013, for which these companies have had high levels of conventional debt that surpassed the benchmarks set by the Securities Commission Malaysia. By identifying the factors that influence capital structure and capital structure decisions, firms will be able to maximize value and strengthen the company's Shariah-compliant financial stability, while remaining listed as Shariahcompliant securities.

The empirical analysis and results reported in this study asserts that firms have target capital structure, and there are specific determinants that would affect the capital structure of Shariah-compliant firms in Malaysia. This study concludes that the lagged dependent variables (lagged leverage 1 and leverage 2) have positive significance on capital structure with speed of adjustment at approximately 2 years. Hence, Shariah-compliant firms close approximately $30 \%$ to $70 \%$ of the gap between current and target capital structure within one and two years. These findings reaffirm that there exist target leverage for all sectors of the Shariah-compliant firms in Malaysia. Moreover, the speed of adjustment from current leverage to the target leverage became faster when the Securities Commission Malaysia (SC) introduced a revised screening methodology in November 2013. Most of the Malaysian Shariah-compliant firms for each sector were considerably affected by the revised screening methodology, particularly with regards to the speed of adjustment towards achieving the target leverage.

The findings have also shown certain implications to large firms. Large firms tend to generate more income and profit, however they require more debt to support investment activities. With regards to profitability, this study identified a negative relationship between profitability and leverage for Shariah-compliant firms for all sectors. Shariah-compliant firms that have high profitability will use a lower leverage for financial activities. Therefore, the results strongly support the pecking order theory. The findings on the target leverage level imply that after the introduction of the revised screening methodology in November 2013, the speed of adjustment improved. The revised screening methodology led to a faster adjustment towards the target leverage level. For example, the speed of adjustment for the Consumer Products sector improved from approximately 2 years (year 1999-2013) to 1 year (2014-2017). In addition, the level of conventional debt was found to be lower after the revised screening methodology was introduced. It is important for firms to achieve the target leverage when making financial decisions, which strengthens the firm's Shariah-compliant financial stability and sustainability, and subsequently enable firms to remain listed as Shariah-compliant securities. Future research on capital structure should be aimed towards the investigation of the effects of target leverage on sustainable growth rate. 


\section{Acknowledgement}

The authors would like to acknowledge The Research and Innovation Management Centre (RIMC) USIM, Nilai and Ministry of Higher Education Malaysia (MOHE) for the financial support of this research. This research is supported by MOHE under the Fundamental Research Grant Scheme (FRGS) with reference code: FRGS/1/2018/SS01/USIM/01/2.

\section{References}

Abdeljawad, I., Mat-Nor, F., Ibrahim, I., \& Abdul-Rahim, R. (2013). Dynamic capital structure trade-off theory: Evidence from Malaysia. International Review of Business Research Papers, 9(6), 102-110.

Ali, M. M., Ibrahim, M. K., Mohammad, R., Zain, M. M., \& Alwi, M. R. (2009). Malaysia: Value relevance of accounting numbers. In Global Practices of Corporate Social Responsibility. Berlin, Heidelberg: Springer Berlin Heidelberg, 201-231.

Al-Najjar, B. (2011). Empirical modelling of capital structure Jordanian evidence. Journal of Emerging Market Finance, 10(1), 1-19.

Al-Yahyaee, K. H., Pham, T. M., \& Walter, T. S. (2013). Capital structure and stock returns: Evidence from an emerging market with unique financing arrangements. Applied Financial Economics, 29(14).

Antoniou, A., Guney, Y., \& Paudyal, K. (2002). The determinants of corporate capital structure: Evidence from European countries. Centre for Empirical Research in Finance, 23-26.

Arellano, M., \& Bond, S. (1991). Some tests of specification for panel data: Monte Carlo evidence and an application to employment equations. The Review of Economic Studies, 58(2), 277.

Arioglu, E., \& Tuan, K. (2014). Speed of adjustment: Evidence from Borsa Istanbul. Borsa Istanbul Review.

Baxamusa, M., \& Jalal, A. (2014). Does religion affect capital structure? Research in International Business and Finance, 31, 112-131.

Bidyut Jyoti Bhattacharjee, \& Faculty of Commerce, B.H College, Howly, Assam, I. (2010). Capital structure decision: An empirical investigation in Indian information technology sector. Smart Journal of Business Management Studies, 6(2), 18-24.

Bonaimé, A. A., Öztekin, O., \& Warr, R. S. (2014). Capital structure, equity mispricing, and stock repurchases. Journal of Corporate Finance, 26, 182-200.

Bouraoui, T., \& Li, T. (2014). The impact of adjustment in capital structure in mergers \& acquisitions on us acquirers' business performance. Journal of Applied Business Research, 30(1), 27-41. 
Brendea, G. (2014). Financing behavior of Romanian listed firms in adjusting to the target capital structure. Finance a Uver-Czech, Journal of Economics and Finance, 64(4), 312-329.

Byoun, S. (2008). How and when do firms adjust their capital structures toward targets? Journal of Finance, 63(6), 3069-3096.

Chan, C. C., \& Chang, Y. H. (2008). Firm-specific stock return variation and capital structure decisions. Applied Economics Letters, 15(4), 293-299.

DeAngelo, H., DeAngelo, L., \& Whited, T. M. (2011). Capital structure dynamics and transitory debt. Journal of Financial Economics, 99(2), 235-261.

Drobetz, W., \& Wanzenried, G. (2006). What determines the speed of adjustment to the target capital structure? Applied Financial Economics, 16, 941-958.

Drobetz, W., Gounopoulos, D., Merikas, A., \& Schröder, H. (2013). Capital structure decisions of globally-listed shipping companies. Transportation Research Part E: Logistics and Transportation Review.

Getzmann, A., Lang, S., \& Spremann, K. (2014). Target capital structure and adjustment speed in asia. Asia-Pacific Journal of Financial Studies, 43(1), 1-30.

Haron, R. (2014). Key factors influencing target capital structure of property firms in Malaysia. Asian Social Science, 10(3), 62-69.

Haron, R. (2016). Do Indonesian firms practice target capital structure? A dynamic approach. Journal of Asia Business Studies, 10(3), 318-334.

Haron, R., \& Ibrahim, K. (2011). Determinants of target capital structure: Evidence on South East Asia countries. Journal of Business and Policy Research, 6(3), 39-61.

Haron, R., \& Ibrahim, K. (2012). Target capital structure and speed of adjustment: Panel data evidence on Malaysia Shariah compliant securities, Journal of Economics Management and Accounting, 20(202), 87-107.

Haron, R., Ibrahim, K., Mat-Nor, F., \& Ibrahim, I. (2013). Factors affecting speed of adjustment to target leverage: Malaysia evidence. Global Business Review, 14(2), 243-262.

Hovakimian, A., \& Li, G. (2011). In search of conclusive evidence: How to test for adjustment to target capital structure. Journal of Corporate Finance, $17(1), 33-44$.

Johnson, R., \& Soenen, L. (2003). Indicators of successful companies. European Management Journal, 21(3), 364-369.

Md. Hashim, A., Habib, F., Isaacs, Z., \& Gadhoum, M. (2007). ISRA Bloomberg Shariah stock screening and income cleansing methodologies: A conceptual paper. ISRA International Journal of Islamic Finance, 9(1), $27-42$.

Muhammad, J. (2015). Shariah-compliant stocks and stock market reaction in Malaysia. Universiti Putra Malaysia Press.

Najib, N. H., Hamid, I. R., Nasarudin, S. N., \& Saiti, B. (2014). The comparison of Shariah screening methodology for stocks between Malaysia Security 
Commission criteria and Dow Jones method: A critical assessment. Paper presented at Unikl Business School Management and Entrepreneurship Conference, Malaysia.

Suffian, M. T. M., Sanusi, Z. M., Osman, A. H., \& Azhari, M. I. M. (2015). Manipulation of earnings: The pressure of opportunistic behavior and monitoring mechanisms in Malaysian Shariah-compliant companies. Procedia Economics and Finance, 31, 213-227.

Zainudin, N., Miskam, S., \& Sulaiman, M. (2014). Revised Shariah screening methodology for Shariah-compliant securities: New standard to meet global expectation. Paper presented at the Conference on Management and Muamalah, International Islamic University College Selangor. 